\title{
Absorption Capacity of Heavy Metals in the Case of Typha Latifolia Plant Species
}

\author{
ALEXANDRA DANA CHITIMUS ${ }^{1}$, VALENTIN NEDEFF ${ }^{1,2 *}$, ION SANDU ${ }^{3,4}$, CRISTIAN RADU ${ }^{5}$, EMILIAN MOSNEGUTU ${ }^{1}$, \\ IOAN GABRIEL SANDU ${ }^{4,6}$, NARCIS BARSAN ${ }^{1 *}$ \\ ${ }^{1}$ Vasile Alecsandri University of Bacau, Faculty of Engineering, 157 Calea Marasesti, 600115, Bacau, Romania \\ ${ }^{2}$ Gheorghe Ionescu Sisesti, Academy of Agricultural and Forestry Sciences, 61 Marasti Blvd., 01146, Bucharest, Romania \\ ${ }^{3}$ Alexandru Ioan Cuza University of lasi, Arheoinvest Interdisciplinary Platform, Scientific Investigation Laboratory, 11 Carol I \\ Blvd., 700506, Iasi, Romania \\ ${ }^{4}$ Romanian Inventors Forum, 3 Sf. Petru Movila St., Bloc L11, III/3, 700089, Iasi, Romania \\ ${ }^{5}$ Romanian Waters - National Administration of Siret Basin, 1 Cuza Voda St., 600274, Bacau, Romania \\ ${ }^{6}$ Gheorghe Asachi Technical University of Iasi, Materials Science and Engineering Faculty, 53A D. Mangeron Blvd., 700050, Iasi, \\ Romania
}

The main objective of the current research is to determine the absorption capacity of heavy metals (zinc and cadmium) in the case of Typha Latifolia plant species (root, stalk, leaf, flower). The plant samples was taken from the Bistrita river banks, respectively upstream of Bacau city, Romania, in Bogdan Voda area, and downstream of Bacau city). A very high absorption capacity of zinc and cadmium was recorded, in the case of Typha Latifolia plant species (especially in the stalk of the plant- $26.91 \div 68.18 \%$, lower that in the root of Typha Latifolia plant species). A lower absorption capacity of zinc and cadmium was recorded, in the flower in the case of Typha Latifolia plant species (84.73 $\div 96.4 \%$ lower that in the root of Typha Latifolia plant species).

Keywords: zinc, cadmium, absorption capacity, Typa Latifolia, Bistrita river

Metals can be found in the soil under various forms associated with mineral and organic components of the solid phase [1-11].

Heavy metals constitute an important category of stable toxic pollutants. Unlike organic pollutants, metals are not biodegradable, they generally have little mobility and, for this reason, they persist in storage compartments (soil, sediments, water surface and underwater) for a long time $[3,12-34]$.

Thus, heavy metals with concentration levels in the soil higher than $0,1 \%$ become toxic for plants, altering the structure of the plant community in a polluted habitat $[3,8$, $9,22,27-37]$.

There are plants which can adapt to and tolerate high metal concentration levels (metallophytes), and there is a limit level for each plant [3, 8-13, 23].

The transport of heavy metals in the soil is carried out in liquid or suspension form, either by means of plant roots or by connecting with microorganisms in the soil $[1-5,8,9]$.

This paper describe the absorption capacity of heavy (zinc and cadmium) in the case of Typha Latifolia plant species (root, stalk, leaf, flower).

\section{Experimental part}

Sections taken into consideration for taking samples of plants are presented in figure 1. The sampling of vegetation was took from two locations/areas along the Bistrita River (Bogdan-Voda, upstream of Bacau city and second location -downstream Bacau city) from the banks of the tributaries [3].

Typha Latifolia (fig. 2) is a plant species which accumulates heavy metals, so its investigation leads to significant results [3].

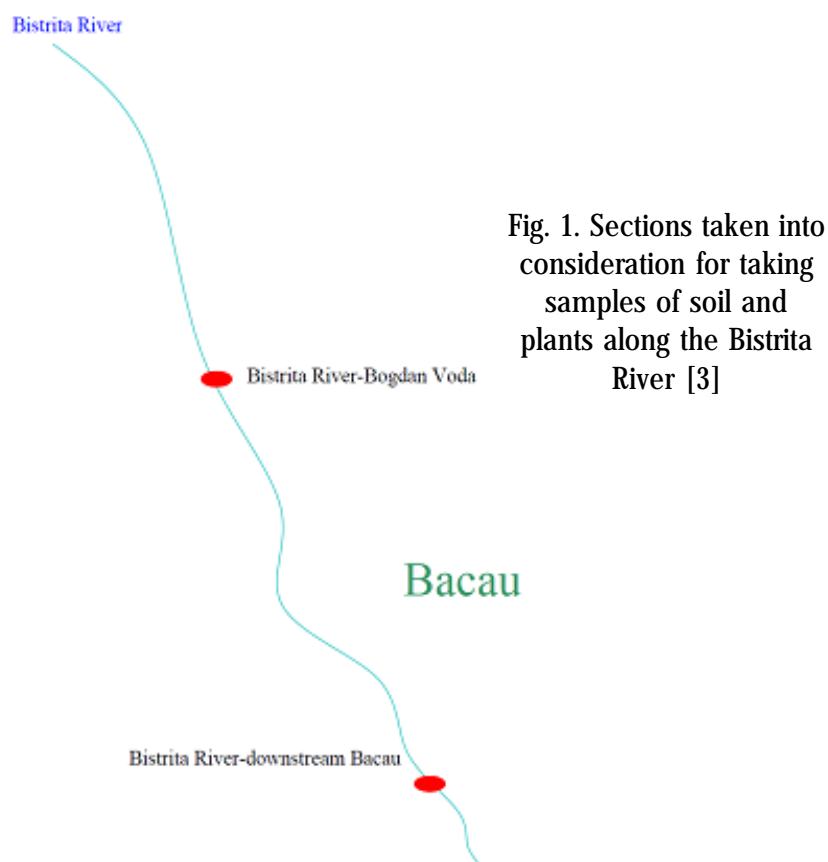

Plants samples were taken for three levels [3]:

- minimum level: soil-water interface level of $0 \mathrm{~cm}$;

- medium level: soil-water interface level of $50 \mathrm{~cm}$, on the river bank;

- maximum level: soil-water interface level of $100 \mathrm{~cm}$, on the river bank.

The zinc and cadmium content in the case of Typha Latifolia plant species has been determined by using the atomic absorption spectrometer (AAS), ZEENIT AAS version (Fig. 3) [38]. 


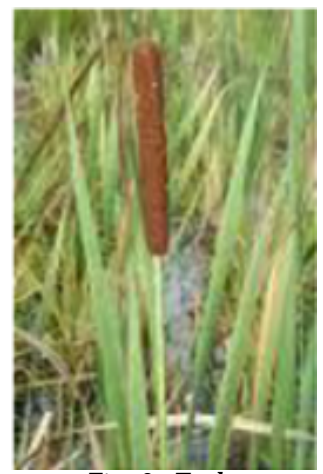

Fig. 2. Typha

Latifolia [3]

\section{Results and discussions}

Figure 4 represents graphically the absorption capacity of cadmium from the soil in the case of Typha Latifolia plant species (root, stalk, leaf, flower) in the sampling point Bistrita River -Bogdan-Voda, upstream of Bacau city.

The highest absorption capacity of cadmium in the sampling point Bistrita River -Bogdan-Voda, upstream of Bacau city, was detected in the root of Typha Latifolia plant species, and the lowest absorption capacity of cadmium was observed in the flower.

The percentage values of the cadmium concentration determined in the stem, leaf and flower compared with the root of the Typha Latifolia plant species for the sampling point Bistrita - Bogdan Voda River, upstream of Bacau, was:

- Steam (for the minimum level of soil-water interface, it was $65.11 \%$ lower than in the root of plant; for the medium level of soil-water interface, it was $57.99 \%$ lower than in the root of plant; for the maximum level of soilwater interface, it was $38.24 \%$ lower than in the root of plant);

- Leaf (for the minimum level of soil-water interface, it was $85.04 \%$ lower than in the root of plant; for the medium level of soil-water interface, it was $94.86 \%$ lower than in the root of plant; for the maximum level of soil-water interface, it was $82.36 \%$ lower than in the root of plant);

- Flower (for the minimum level of soil-water interface, it was $93.35 \%$ lower than in the root of plant; for the medium level of soil-water interface, it was $97.54 \%$ lower than in the root of plant; for the maximum level of soilwater interface, it was $96.4 \%$ lower than in the root of plant).

Figure 5 represents graphically the absorption capacity of zinc from the soil in the case of Typha Latifolia plant

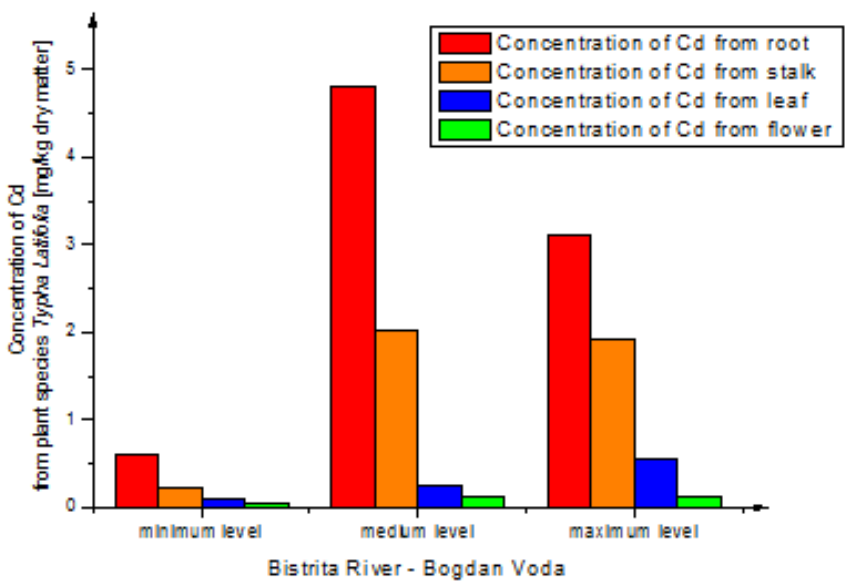

Fig. 4. The absorption capacity of cadmium from the soil in the case of Typha Latifolia plant species (root, stalk, leaf, flower) in the sampling point Bistrita River - Bogdan-Voda, upstream of Bacau city species (root, stalk, leaf and flower) in the sampling point Bistrita River - Bogdan-Voda, upstream of Bacau city.

The highest absorption capacity of zinc in the sampling Bistrita River - Bogdan-Voda, upstream of Bacãu city, was detected in the root of Typha Latifolia plant species, and the lowest absorption capacity of cadmium was observed in the flower. The values of zinc concentration detected in the stalk were much higher than those from the leaf of Typha Latifolia plant species.

The percentage values of the zinc concentration determined in the stem, leaf and flower compared with the root of the Typha Latifolia plant species for the sampling point Bistrita - Bogdan Voda River, upstream of Bacau, was:

- Steam (for the minimum level of soil-water interface, it was $62.33 \%$ lower than in the root of plant; for the medium level of soil-water interface, it was $30.21 \%$ lower than in the root of plant; for the maximum level of soilwater interface, it was $25.21 \%$ lower than in the root of plant);

- Leaf (for the minimum level of soil-water interface, it was $80.5 \%$ lower than in the root of plant; for the medium level of soil-water interface, it was $67.76 \%$ lower than in the root of plant; for the maximum level of soil-water interface, it was $58.57 \%$ lower than in the root of plant);

- Flower (for the minimum level of soil-water interface, it was $89.98 \%$ lower than in the root of plant; for the medium level of soil-water interface, it was $93.81 \%$ lower than in the root of plant; for the maximum level of soilwater interface, it was $91.86 \%$ lower than in the root of plant).

Figure 6 represents graphically the absorption capacity of cadmium from the soil in the case of Typha Latifolia plant species (root, stalk, leaf and flower) in the sampling point Bistrita River - downstream Bacau, downstream of Bacau city.

The highest absorption capacity of cadmium from the soil, in Bistrita River -downstream Bacãu, downstream of BacAu city, was detected in the root of Typha Latifolia plant species, whereas the low est absorption capacity levels of cadmium were observed in its leaf and flower.

The values of the cadmium concentration determined in the stem, leaf and flower compared with the root of the Typha Latifolia plant species for the sampling point Bistrita River - downstream Bacãu, downstream of Bacau, was:

- Steam (for the minimum level of soil-water interface, it was $44.72 \%$ lower than in the root of plant; for the medium level of soil-water interface, it was $65.53 \%$ lower

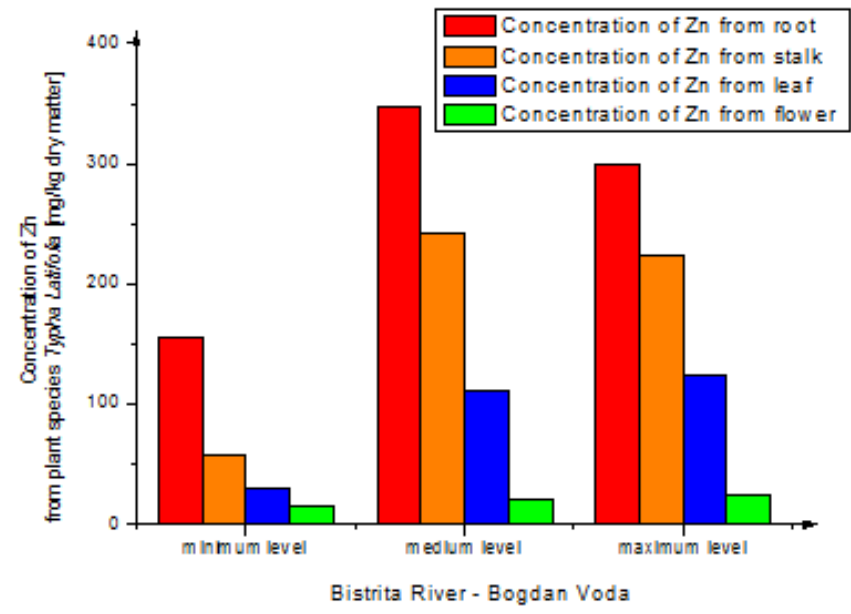

Fig. 5. The absorption capacity of zinc from the soil in the case of Typha Latifolia plant species (root, stalk, leaf, flower) in the sampling point Bistrita River - Bogdan-Voda, upstream of Bacau city 


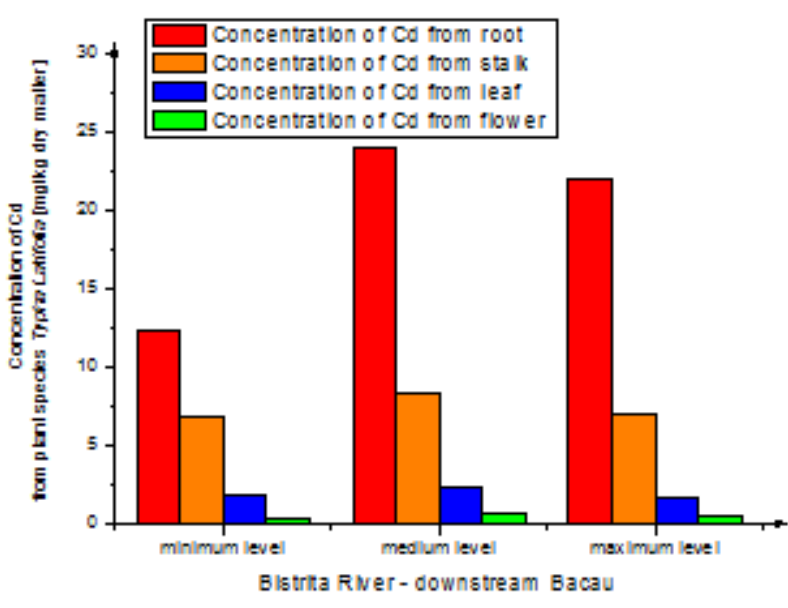

Fig. 6. The absorption capacity of cadmium from the soil in the case of Typha Latifolia plant species (root, stalk, leaf, flower) in the sampling point Bistrita River - downstream Bacau, downstream of Bacau city

than in the root of plant; for the maximum level of soilwater interface, it was $68.18 \%$ lower than in the root of plant);

- Leaf (for the minimum level of soil-water interface, it was $87.73 \%$ lower than in the root of plant; for the medium level of soil-water interface, it was $89.87 \%$ lower than in the root of plant; for the maximum level of soil-water interface, it was $92.94 \%$ lower than in the root of plant);

- Flower (for the minimum level of soil-water interface, it was $97.28 \%$ lower than in the root of plant; for the medium level of soil-water interface, it was $97.04 \%$ lower than in the root of plant; for the maximum level of soilwater interface, it was $97.48 \%$ lower than in the root of plant).

Figure 7 represents graphically the absorption capacity of zinc from the soil in the case of Typha Latifolia plant species (root, stalk, leaf, flower) in the sampling Bistrita River - downstream Bacau, downstream of Bacau city.

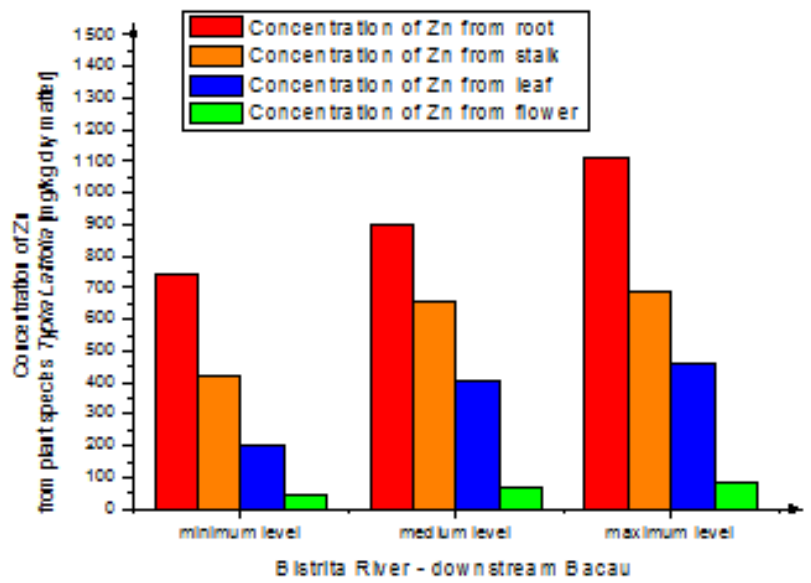

Fig. 7. The absorption capacity of zinc trom the soil in the case of

Typha Latifolia plant species (root, stalk, leaf, flower) in the sampling point Bistrita River - downstream Bacau, downstream of Bacau city

The highest absorption capacity of zinc in the sampling point Bistrita River - downstream Bacau, downstream of Bacau city, was detected in the root of Typha Latifolia plant species, and the lowest absorption capacity of cadmium was observed in the flower.

The percentage values of the zinc concentration determined in the stem, leaf and flower compared with the root of the Typha Latifolia plant species for the sampling point Bistrita River - downstream Bacau, downstream of Bacau, was:

- Steam (for the minimum level of soil-water interface, it was $42.99 \%$ lower than in the root of plant; for the medium level of soil-water interface, it was $26.91 \%$ lower than in the root of plant; for the maximum level of soilwater interface, it was $37.86 \%$ lower than in the root of plant);

- Leaf (for the minimum level of soil-water interface, it was $72.84 \%$ lower than in the root of plant; for the medium level of soil-water interface, it was $55.23 \%$ lower than in the root of plant; for the maximum level of soil-water interface, it was $58.65 \%$ lower than in the root of plant);

- Flower (for the minimum level of soil-water interface, it was $94.07 \%$ lower than in the root of plant; for the medium level of soil-water interface, it was $92.29 \%$ lower than in the root of plant; for the maximum level of soilwater interface, it was $92.64 \%$ lower than in the root of plant).

\section{Conclusions}

The studies conducted in the urban residential area of Bacau show that upstream of Bacau city there is no significant presence of heavy metals in the soil but important loads can be detected on the Bistrita River, downstream of Bacau city. These loads result from the industrial platform of Bacau city and from the discharge of municipal wastewater produced throughout the ages.

In relation this aspect, significant loading rates for cadmium, and zinc were identified both in the soil and in Typha Latifolia plant species.

The values of the concentration of cadmium detected in the flower of Typha Latifolia in the sampling points Bistrita River - Bogdan-Voda, upstream of Bacau city and in Bistrita River - downstream Bacau, downstream of Bacau city were $84.73 \% \div 96.4 \%$ lower than in its roots.

The values of the concentration of zinc detected in the flower of Typha Latifolia in the sampling points Bistrita River-Bogdan-Voda, upstream of Bacau city and in Bistrita River - downstream Bacau, downstream of Bacau city were $89.98 \% \div 94.07 \%$ lower than in its roots.

Comparing the absorption capacity of heavy metals from the soilin the case of Typha Latifolia plant species it was observed that it is a very good accumulator of cadmium and zinc in the root of the plant.

Typha Latifolia plant species proved to be a very good accumulators of heavy metals, especially in their roots, a fact which shows that they can be used in soil phytoremediation processes, particularly in phyto-extraction and phyto-stabilisation processes for the removal of heavy metals from contaminated soils.

\section{References}

1. SENILA, M., LEVEI, E., MICLEAN, M., SENILA, L., STEFANESCU, L., MARGINEAN, S., OZUNU, A., ROMAN, C., Environmental Engineering And Management J ournal, 10, 2011, p. 59.

2. DRAGOVIC, S., MIHAILOVIC, N., GAJIC, B., Chemosphere, 72, 2008, p. 491.

3.RADU, C., Studies and research on the ecological impact of residual soil pollution by heavy metals on tributaries banks from the Siret hydrographic basin, PhD Thesis, Vasile Alecsandri University of Bacau, Romania, 2015.

4.ABDERRAHIM, G., European J ournal of Scientific Research, 32, 2009, p. 58.

5.KO, I., CHANG, Y., LEE, C., KIM, W., J ournal of Hazardous Materials, 127,2005, p. 1. 
6.BELCIU, M.C., NEDEFF, V., CHIPIMUa , A.D., BARSAN, N., RUSU, D., Journal of Engineering Studies and Research, 22, no. 1, 2016, p. 15. 7. FORTUNA, M.E., SIMION, I.M., GAVRILESCU, M., Environmental Engineering and Management J ournal, 10, 2011, p. 1987.

8.RADU, C., CHITIMUa , A.D., TURCU, M., ARDELEANU, G., BELCIU, M., Environmental Engineering and Management Journal, 13, no. 7, 2014, p. 1687.

9.RADU, C., NEDEFF, V., CHITIMUS, A.D., J ournal of Engineering Studies and Research, 19, no. 2, 2013, p. 89.

10.AL-MOMANI, I.F., J ordan Journal of Chemistry, 4, 2009, p. 77.

11. BELCIU, M.C., NEDEFF, V., CHITIMUS, A.D., RADU, C., J ournal of Engineering Studies and Research, 20, no. 1, 2017, p. 23.

12.ACKOVA, D.G., Plant Science Today, 5, no. 1, 2018, p. 14.

13.CHITIMUS, A.D., NEDEFF, V., LAZAR, G., MACARESCU, B., MOSNEGUTU, E., Journal of Engineering Studies and Research, 17, no. 1, 2011, p. 13.

14.NAGAJYOTI, P.C., LEE, K.D., SREEKANTH, T.V.M., Environmental Chemistry Letter, 8, 2010, p. 199.

15.MUSCALU (PLESCAN), O.M., NEDEFF, V., CHITIMUS, A.D., PARTAL, E., MOSNEGUTU, E., RUSU, I.D., Rev. Chim (Bucharest), 69, no. 11, 2018, p. 3106.

16.GULERYUZ, G., ARSLAN, H., CELIK, C., GUCER, S., KENDALL, M., Water Air Soil Pollution, 195, 2008, p. 275.

17.KIM, Y., KIM, B.K., KIM, K., Environmental Earth Sciences, 60, 2009, p. 943.

18.MUSCALU (PLESCAN), O.M., NEDEFF, V., CHITIMUS, A.D., PARTAL, E., BARSAN, N., RUSU, I.D, Rev. Chim (Bucharest), 70, no. 2, 2019, p. 536.

19.CHITIMUS, A.D., BARSAN, N., NEDEFF, V., MOSNEGUTU, E., MUSCALU (PLESCAN), O., Studies and research concerning the influence of liquid pollutants' leaching speed in the soil on the process of cleaning and self-cleaning, 17th International Multidisciplinary Scientific GeoConference SGEM 2017, 17, no. 51, 2017, pp. 859-866.

20.WARNE, M.S., HEEMSBERGEN, D., STEVENS, D., COZENS, G., WHATMUFF, M., BROOS, K., BARRY, G., BELL, M., NASH, D., PRITCHARD, D., PENNEY, N., Environmental Toxicology Chemistry, 27, 2008, p. 786.

21.MUSCALU (PLESCAN), O.M., NEDEFF, V., PARTAL, E., MOSNEGUTU, E., SANDU, I.G., SANDU, I., BARSAN, N., RUSU, D., Rev. Chim (Bucharest), 70, no. 5, 2019, p. 1726.

22.CHITIMUS, A.D., RADU, C., NEDEFF, V., MOSNEGUTU, E., BARSAN, N., Scientific Study \& Research Chemistry $\&$ Chemical Engineering, Biotechnology, Food Industry, 17, no. 4, 2016, p. 381.
23.VERSIEREN, L., EVERS, S., ABDELGAWAG, H., ASARD, H., SMOLDERS, E., Environmental Toxicology Chemistry, 36, 2017, p. 220.

24.CHITIMUS, A.D., MOSNEGUTU, E., NICOLESCU, M.C., TURCU M., BELCIU, M.C., ARDELEANU, G., Environmental Engineering \& Management J ournal, 13, no. 7, 2014, p. 1581.

25.CHARKRAVARTY, M., PATGIRI, A.D., Journal of Human Ecology, 27, 2009, p. 63.

26. CHITIMUS, A.D., NEDEFF, V., MOSNEGUTU, E., PANAINTE, M., Environmental Engineering and ManagementJ ournal, 11, no. 12, 2012, p. 2163.

27.SINGH, R., GAUTAM, N., MISHRA, A., GUPTA, R Indian J ournal Pharmacology, 43, 2011, p. 246.

28.MOSNEGUTU, E.F., NEDEFF, V., CHITIMUS, A.D., RUSU, D.I., J OITA, I., International Journal of Conservation Science, 10, no. 1, 2019, p. 131.

29. LUPOAE, P., TUPU, E., ONEA, N., MURARIU, G., GEORGESCU, L., TUDOR, M., ITICESCU, C., LUPOAE, M., International J ournal of Conservation Science, 10, no. 1, 2019, p. 149.

30. IACOBAN, C., RISCA, I.M., ROIBU, C., CIORNEA, E.T., NECULA, R., ILIEVA, D., SANDU, I., DROCHIOIU, G., Rev. Chim (Bucharest), 70, no. 3, 2019, p. 753.

31. NECULA, R., GILLE, E., DIRTU, A.C., SANDU, I., GRADINARU, V.R., PETCU, A., DROCHIOIU, G., Rev. Chim (Bucharest), 69, no. 7, 2018, p. 1682.

32. CIORNEA, E.T., DUMITRU, G., ZAHARIA, M., DROCHIOIU, G., SANDU, I., Rev. Chim (Bucharest), 69, no. 2, 2018, p. 449.

33. PAPADATU, C.P., BORDEI, M., ROMANESCU, G., SANDU, I., Rev. Chim (Bucharest), 67, no. 9, 2016, p. 1728.

34. CHITIMUS, A.D., NEDEFF, V., SANDU, I., RADU, C., MOSNEGUTU, E., SANDU, I.G., BARSAN, N., Rev. Chim (Bucharest), 70, no. 7, 2019, p. $x x x$

35. CHITIMUS, D., COCHIORCA, A., NEDEFF, V., MUSCALU, O., BARSAN, N., Studies and Research on Phragmites Australis' (Common Reed) Absorption Capacity of Heavy Metals From the Soil in Roman City, Romania, Proceeding of the International Multidisciplinary Scientific GeoConference Surveying Geology and Mining Ecology Management, SGEM, 2018, 18, 2018, pp. 671-678.

36. LIANG, J., CHEN, C., SONG, X., HAN, Y., LIANG, Z., International J ournal of Electrochemical Science, 6, 2011, p. 5314.

37. CHITIMUS, A.D., NEDEFF, V., LAZAR, G., Journal of Engineering Studies and Research, 17, no. 4, 2011, p. 24.

38.*** Atomic absorption spectrometry (AAS) ZEEnit 700, Operating Manual, 2009.

$\overline{\text { Manuscript received: } 9.02 .2019}$ 